\title{
Hyperglycaemia as an inducer as well as a consequence of impaired islet cell function and insulin resistance: implications for the management of diabetes
}

\author{
R.H. Unger and S. Grundy \\ Veterans Administration Medical Center and Department of Internal Medicine, University of Texas Health Science Center, Dallas, Texas, USA
}

\begin{abstract}
Summary. It is postulated that hyperglycaemia influences the natural history of Type 1 (insulin-dependent) and Type 2 (noninsulin-dependent) diabetes mellitus. Hyperglycaemia, even when mild, can attenuate the secretory response of pancreatic $\beta$ and $\alpha$ cells to increments in glucose and can impair insulinmediated glucose transport, thus impeding its own correction and initiating a cycle of progressive self-exacerbation and metabolic deterioration. Both reduced islet function and insulin action may be the consequence of a generalized down-regulation and/or occupation of glucose transporters by hyperglycaemia so that the islets respond less to further increments in glycaemia. The postulated hyperglycaemic cycle can be initiated by any environmental perturbation that increases insu-
\end{abstract}

lin demand in previously normoglycaemic patients in whom insulin secretion has already reached a maximum level of compensation for peripheral insulin resistance (as in obese pre-Type 2 diabetes) or for a reduced $\beta$-cell mass (as in preType 1 diabetes). Elimination of hyperglycaemia by any means can halt this cycle of progressive metabolic deterioration and may restore transiently metabolic recompensation both in Type 1 and Type 2 diabetes. There is experimental evidence that long-standing severe hyperglycaemia may irreversibly damage $\beta$ cells.

Key words: Hyperglycaemia, islet cell function, insulin, glucagon, diabetic remissions, Type 1 diabetes, Type 2 diabetes.

\section{The hyperglycaemia hypothesis}

It is postulated that hyperglycaemia, by directly attenuating responses of the pancreatic islets to increments in blood glucose concentration and reducing insulin-mediated glucose transport in peripheral tissues, influences the natural history of diabetes mellitus. Hyperglycaemia may be provoked by an environmental perturbation that increases insulin demand and/or decreases insulin supply in a previously normoglycaemic individual whose $\beta$ cells are already secreting at a maximal level to compensate for a reduction in $\beta$-cell mass or insulin resistance. By reducing the responses that prevent more severe hyperglycaemia, an initially mild hyperglycaemic state may launch a self-exacerbating cycle of metabolic deterioration (Fig. 1). Any intervention that abolishes the hyperglycaemia may restore both islet cell function and glucose transport towards normal and thus re establish a metabolically compensated state.

\section{Evidence that hyperglycaemia impairs islet cell function}

Acute insulin response to intravenously injected glucose is impaired in subjects with fasting plasma glucose levels $>6.4 \mathrm{mmol} / 1$ [1]. Although functional loss is ini- tially restricted to glucose, when the fasting plasma glucose level exceeds $11.1 \mathrm{mmol} / 1 \beta$ cells become unresponsive to other secretagogues [1]. This glucose-restricted loss of the insulin response to intravenous glucose is observed in pre-overt Type 1 diabetes as well as in Type 2 diabetes [2]. Loss of the $\alpha$ cell response to glucose [3] parallels the glucose unresponsiveness of $\beta$ cells [4] and both are restored to normal by eliminating the hyperglycaemia whether by diet, sulphonylureas, insulin or phloridzin glucuresis [5-10]. This raises the possibility that the defect is secondary to a hyperglycaemiainduced reduction in available glucose transporters similar to that induced by hyperglycaemia in adipocytes [11] and at the blood-brain barrier $[12,13]$.

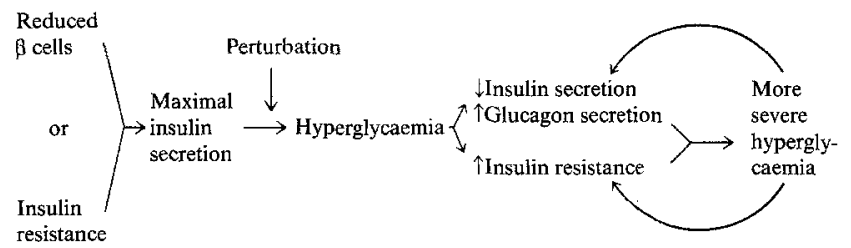

Fig. 1. Initiation of hyperglycaemia and the cycle of self-exacerbation. "Perturbation" refers to any environmental factor, illness, weight gain or carbohydrate excess that would unfavourably alter the balance between insulin production and insulin need 
It is reported that high glucose levels ultimately may cause irreversible damage to $\beta$ cells both in vivo [14] and in vitro [15]. Damage in vivo is prevented by reduction in hyperglycaemia [16].

\section{Evidence that hyperglycaemia causes insulin resistance}

Insulin resistance unrelated to obesity occurs in various hyperglycaemic states [17-19] and is corrected by elimination of the hyperglycaemia with insulin $[19,20]$. Since the resistance seems restricted to insulin-mediated effects on glucose transport [21], it could reflect depletion of intracellular glucose transport systems in insulin-requiring tissues [11-13], which would produce a "postreceptor" form of insulin resistance [22, 23].

\section{Role of hyperglycaemia in the natural history of diabetes}

\section{Type I diabetes}

During the pre-hyperglycaemic phase of $\beta$-cell destruction in patients destined to develop Type 1 diabetes, the production of insulin keeps pace with insulin demand through compensatory hypersecretion by the surviving $\beta$ cells. However, once compensatory insulin secretion has reached its maximum level, a further increase in insulin demand consequent to stressful illness, weight gain or high carbohydrate intake would initiate hyperglycaemia and begin the cycle of progressive metabolic deterioration. Aggressive insulin therapy early on can induce a remission in over $70 \%$ of such patients [24] by interrupting and reversing the cycle, thus restoring compensation until a new perturbation or further immunological damage supervenes.

\section{Type 2 diabetes}

In many patients destined to develop Type 2 diabetes, compensated obesity-related insulin resistance may precede hyperglycaemia. Although the $\beta$ cells may be numerically normal [25], they must hypersecrete to maintain normoglycaemia in the face of insulin resistance. When compensatory insulin secretion has reached a maximum level, a further increase in insulin demand due to stressful illness, weight gain or dietary excess may initiate a hyperglycaemic state and begin a gradual cycle of progressive but reversible metabolic deterioration by reducing islet responses and insulin effectiveness. Thus, hyperglycaemia may be the long-sought link between pre-existing peripheral insulin resistance and the hitherto unexplained failure of islet cells to maintain full compensation [26-28], so-called "exhaustion".

\section{Therapeutic and prophylactic implications}

The hyperglycaemia hypothesis provides a novel rationale for meticulous control of glycaemia, namely induction and maintenance of a metabolic remission through improved islet cell responses to glucose and reduced hyperglycaemia-related insulin resistance. In the compensated pre-hyperglycaemic phase of diabetes, measures that prevent hyperglycaemia might postpone decompensation to the overt diabetic state. Avoidance of perturbations that increase insulin demand together with pharmacological enhancement of insulin production (sulphonylureas reportedly reduce the 10 -year incidence of overt Type 2 diabetes in individuals with impaired glucose tolerance [29]), may deserve careful evaluation. In established Type 2 diabetes, the possibility that aggressive short-term correction of hyperglycaemia may induce a worthwhile remission beyond the 2 weeks already reported also warrants consideration.

Acknowledgements. This work supported by VA Institutional Research Support grant 549-8000-01 and National Institutes of Health grant AM-02700-25.

\section{References}

1. Pfeiffer MA, Halter JB, Porte D Jr (1981) Insulin secretion in diabetes mellitus. Am J Med 70: 579-588

2. Ganda OP, Gleason RE, Srikanta S, Soeldner JS (1984) B-cell secretory response in monozygotic twins of HLA-DR4 Type 1 diabetics is not increased. Diabetes 33 (Suppl 1): $37 \mathrm{~A}$

3. Müller WA, Faloona GR, Aguilar-Parada E, Unger RH (1970) Abnormal alpha cell function in diabetes. Response to carbohydrate and protein ingestion. N Engl J Med 283: 109-115

4. Hatfield HH, Banasiak MF, Driscoll T, Kim H-J, Kalkhoff RK (1977) Glucose suppression of glucagon: relationship to pancreatic beta cell function? J Clin Endocrinol Metab 44: 1080-1087

5. Starke A, McGarry JD, Unger RH (1984) Evidence for direct glucose response by alpha-cells and its attenuation by hyperglycaemia. Diabetes 33 (Suppl 1): $80 \mathrm{~A}$

6. Savage PJ, Bennion LJ, Flock EV, Nagulesparan M, Mott D, Roth J, Unger RH, Bennett PH (1979) Diet-induced improvement of abnormalities in insulin and glucagon secretion and in insulin receptor binding in diabetes mellitus. J Clin Endocrinol Metab 48: 999-1007

7. Kosaka K, Kuzuya T, Akanuma Y, Hagura R (1980) Increase in insulin response after treatment of overt maturity-onset diabetes is independent of the mode of treatment. Diabetologia 18: 23-28

8. Hidaka H, Nagulesparan M, Klimes I, Clark R, Sasaki H, Aronoff SL, Vasquez B, Rubenstein AH, Unger RH (1982) Improvement of insulin secretion but not insulin resistance after short term control of plasma glucose in obese Type II diabetics. J Clin Endocrinol Metab 54: 217-222

9. Vague P, Moulin J-P (1982) The defective glucose sensitivity of the $\mathrm{B}$ cell in non insulin dependent diabetes. Improvement after twenty hours of normoglycemia. Metabolism 31: 139-142

10. Hermansen K, Schmitz O, Orskov H (1984) Reversal of D and A cell insensitivity to glucose in alloxan diabetic dogs by treatment with the artificial betacell (Biostator). Diabetes 33 (Suppl 1): $81 \mathrm{~A}$

11. Karnieli E, Hissin PJ, Simpson IA, Salans LB (1981) A possible mechanism of insulin resistance in the rat adipose cell in streptozotocin-induced diabetes mellitus. Depletion of intracellular glucose transport systems. J Clin Invest 68: 811-814

12. Gjedde A, Crone C (1981) Blood-brain glucose transfer: repression in chronic hyperglycemia. Science $214: 456-457$

13. McCall AL, Millington WR, Wurtman RJ (1982) Metabolic fuel and amino acid transport into the brain in experimental diabetes mellitus. Proc Natl Acad Sci 79: 5406-5410

14. Dohan FC, Lukens FEW (1947) Lesions of the pancreatic islets produced in cats by administration of glucose. Science 105: 183 
15. Collier SA, Mandel TE, Carter WM (1982) Detrimental effect of high medium glucose concentration on subsequent endocrine function of transplanted organcultured foetal mouse pancreas. Aust J Exp Biol Med Sci 60: 437-445

16. Clarke A, Bowen E, King T, Vanhegan RI, Turner RC (1982) Islet changes induced by hyperglycemia in rats. Effect of insulin or chlorpropamide therapy. Diabetes 31:319-325

17. DeFronzo RA, Hendler R, Simonson D (1982) Insulin resistance is a prominent feature of insulin-dependent diabetes. Diabetes 31 : 795-801

18. Reaven GM, Sageman WS, Swenson RS (1977) Development of insulin resistance in normal dogs following alloxan-induced insulin deficiency. Diabetologia 13: 459-462

19. Andrews WJ, Vasquez B, Nagulesparan M, Klimes I, Foley J, Unger RH, Reaven GM (1984) Insulin therapy in obese noninsulin dependent diabetes induces improvements in insulin action and secretion which are maintained for two weeks after insulin withdrawal. Diabetes 33: 634-642

20. Scarlett JA, Gray RS, Griffin J, Olefsky JM, Kolterman OG (1982) Insulin treatment reverses the insulin resistance of Type II diabetes mellitus. Diabetes Care 5: 353-363

21. Howard BV, Savage PJ, Nagulesparan M, Bennion LJ, Unger RH, Bennett PH (1979) Evidence for marked sensitivity to the antilipolytic action of insulin in obese maturity-onset diabetics. Metabolism 28: 744-750

22. Kasuga M, Akanuma Y, Iwamoto Y, Kosaka K (1978) Insulin binding and glucose metabolism in adipocytes of streptozotocindiabetic rats. Am J Physiol 235: E175-E182
23. Olefsky JM, Kolterman OG (1981) Mechanisms of insulin resistance in obesity and noninsulin-dependent (Type II) diabetes. Am J Med 70: 151-168

24. Mirouze J, Selam JL, Pham TC, Mendoza E, Orsetti A (1978) Sustained insulin-induced remissions of juvenile diabetes by means of an external artificial pancreas. Diabetologia 14: 223-227

25. Rahier J, Goebbels RM, Henquin JC (1983) Cellular composition of the human diabetic pancreas. Diabetologia 24: $366-371$

26. Weir GC (1982) Non-insulin-dependent diabetes mellitus: interplay between B-cell inadequacy and insulin resistance. Am J Med 73: 461-464

27. DeFronzo RA, Ferranini E (1982) The pathogenesis of non-insulin-dependent diabetes. An update. Medicine 61: 125 -140

28. Reaven GM (1984) Insulin secretion and insulin action in non-insulin-dependent diabetes mellitus: which defect is primary? Diabetes Care 7 (Suppl 1): 17-24

29. Sartor G, Schersten B, Carlstrom S, Melander A, Norden A, Persson $G$ (1980) Ten-year follow-up of subjects with impaired glucose tolerance. Prevention of diabetes by tolbutamide and diet regulation. Diabetes 29: 41-49

Dr. R. H. Unger

Department of Internal Medicine

University of Texas Health Science Center at Dallas

5323 Harry Hines Boulevard

Dallas

Texas 75235

USA 